\title{
Dipstick proteinuria is an independent predictor of high on treatment platelet reactivity in patients on clopidogrel, but not aspirin, admitted for major adverse cardiovascular events.
}

\author{
Carlos D. Davila \\ Einstein Medical Center \\ Fernando Vargas \\ Einstein Medical Center \\ Kuan-Hsiang Gary Huang \\ Einstein Medical Center
}

Fbløwabiß/danditional works at: https://jdc.jefferson.edu/cardiologyfp

zistein Medical Center

Part of the Cardiology Commons Arastasiosspimow how access to this document benefits you
Einstein Medical Center

\section{Recommended Citation}

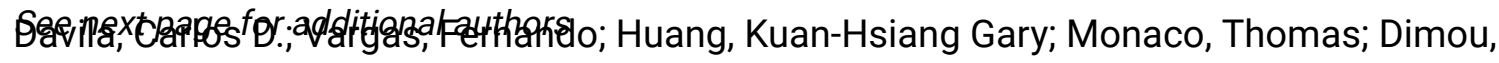
Anastasios; Rangaswami, Janani; and Figueredo, M.D., Vincent M., "Dipstick proteinuria is an independent predictor of high on treatment platelet reactivity in patients on clopidogrel, but not aspirin, admitted for major adverse cardiovascular events." (2014). Division of Cardiology Faculty Papers. Paper 51.

https://jdc.jefferson.edu/cardiologyfp/51

This Article is brought to you for free and open access by the Jefferson Digital Commons. The Jefferson Digital Commons is a service of Thomas Jefferson University's Center for Teaching and Learning (CTL). The Commons is a showcase for Jefferson books and journals, peer-reviewed scholarly publications, unique historical collections from the University archives, and teaching tools. The Jefferson Digital Commons allows researchers and interested readers anywhere in the world to learn about and keep up to date with Jefferson scholarship. This article has been accepted for inclusion in Division of Cardiology Faculty Papers by an authorized administrator of the Jefferson Digital Commons. For more information, please contact: JeffersonDigitalCommons@jefferson.edu. 


\section{Authors}

Carlos D. Davila; Fernando Vargas; Kuan-Hsiang Gary Huang; Thomas Monaco; Anastasios Dimou; Janani Rangaswami; and Vincent M. Figueredo, M.D. 
Dipstick Proteinuria is an Independent Predictor of High on Treatment Platelet Reactivity in Patients on Clopidogrel, but not Aspirin, Admitted for Acute

\section{Cardiovascular Events}

Carlos D. Davila, MD ${ }^{\mathrm{a}}$ Fernando Vargas, MD ${ }^{\mathrm{a}}$ Kuan-Hsiang Gary Huang, MD PhD Thomas Monaco, MD ${ }^{\mathrm{a}}$ Anastasios Dimou, MD Janani Rangaswami, MD ${ }^{\mathrm{a}, \mathrm{b}}$ Vincent M. Figueredo MD ${ }^{\mathrm{c}, \mathrm{d}}$ a - Department of Medicine, Einstein Medical Center, Philadelphia, PA. b - Delaware Valley Nephrology \& Hypertension Group, Philadelphia, PA. c - Einstein Institute for Heart and Vascular Health, Einstein Medical Center, Philadelphia, PA.

c - Jefferson Medical College, Philadelphia, PA.

Authors take responsibility for all aspects of the reliability and freedom from bias of the data presented and their discussed interpretation

Conflict of Interest: none

Funding: none

Keywords: Platelet reactivity, spot dipstick proteinuria, adverse cardiovascular event. Word count:

\section{Corresponding author:}

Carlos D. Davila, MD.

Einstein Medical Center, Klein 363

5501 Old York Road, Philadelphia, PA 19141, USA.

Phone number: 215-456-7890

Fax number: 215-456-3533

email: davilacc@einstein.edu 


\section{Abstract}

Background: The effectiveness of aspirin and clopidogrel in patients with chronic kidney disease (CKD) suffering acute cardiovascular events (ACE) is unclear. High on treatment platelet reactivity (HTPR) has been associated with worse outcomes. Here we assessed the association of dipstick proteinuria (DP) and renal function on HTPR and clinical outcomes.

Methodology: Retrospective cohort analysis of 261 consecutive, non-dialysis patients admitted for ACE (acute coronary syndrome or stroke) that had VerifyNow P2Y12 and VerifyNow Aspirin assays performed. HTPR was defined as P2Y12 reactivity unit (PRU)>208 for clopidogrel and aspirin reaction units (ARU)>550 for aspirin. Renal function was classified based on estimated glomerular filtration rate (eGFR) and dipstick proteinuria was defined as $\geq 30 \mathrm{mg} / \mathrm{dL}$ of albumin detected on a spot analysis. All cause mortality, readmissions, and cardiac catheterizations were reviewed over 520 days.

Results: In patients on clopidogrel $(\mathrm{n}=106)$, DP was associated with HTPR, independent of eGFR, diabetes mellitus, smoking or use of proton pump inhibitor $(\mathrm{AOR}=5.2, \mathrm{p}=0.017)$. In patients with acute coronary syndromes, HTPR was associated with more cardiac catheterizations $(\mathrm{p}=0.009)$ and readmissions $(\mathrm{p}=0.032)$, but no differences in in-stent thrombosis or re-stenosis were noted in this cohort. In patients on aspirin $(n=155)$, no associations were seen between DP and HTPR. However, all cause mortality was significantly higher with HTPR in this group $(\mathrm{p}=0.038)$.

Conclusion: In this cohort, DP is an independent predictor of HTPR in patients on clopidogrel, but not aspirin, admitted to the hospital for ACE.

\section{Introduction}


Randomized clinical trials confirm the benefits of antiplatelet therapy in both primary and secondary prophylaxis of acute cardiovascular events (ACE) $)^{1,2}$. Aspirin, an irreversible cyclooxygenase inhibitor, and clopidogrel, an adenosine diphosphate receptor inhibitor, are the two most widely used antiplatelet medications ${ }^{3}$. High on treatment platelet reactivity (HTPR) in both antiplatelet agents has been associated with worse outcomes in patients with acute coronary syndromes (ACS) and in those undergoing percutaneous coronary interventions $(\mathrm{PCI})^{4-7}$.

The benefit and effect of antiplatelet therapy in patients suffering chronic kidney disease $(\mathrm{CKD})$ remains unclear due to their exclusion from many clinical trials ${ }^{8}$. Recent studies have suggested possible links between CKD based on the extent of estimated glomerular filtration rate (eGFR) impairment, with $\mathrm{HTPR}^{9-11}$. However, given the diversity in kidney disease pathogenesis, whether this link was due directly to the eGFR, or other underlying pathophysiological events remains unknown.

Albuminuria is considered an important predictor of endothelial dysfunction and systemic inflammation, regardless of the degree of renal impairment, and is also a major predictor of cardiovascular morbidity and mortality, especially in diabetic patients $^{12-14}$. In this study we assessed the relationship between renal function and albuminuria as detected on a spot urine dipstick on platelet reactivity and clinical outcomes. 


\section{Methods}

\section{Patients and Selection Criteria}

Two hundred eighty five consecutive adult patients who had on treatment platelet function measurement at the time of admission to Einstein Medical Center (Philadelphia, PA) for acute cardiovascular events (ACE) between January 1st 2012 and March 31st 2013 were studied retrospectively. Patients were identified using ICD-9 codes at the time of admission and electronic medical records were extensively reviewed for confirmation. Although platelet reactivity is not routinely performed in our institution, the decision to undergo testing was driven by the physician on record based on his/her clinical decision-making. All patients were receiving aspirin (81 to $325 \mathrm{mg}$ ) and/or clopidogrel (75 $\mathrm{mg}$ ) according to their home medication list and pharmacy records when available at the time of the admission. Subjects were grouped based on the platelet reactivity test performed at the time of admission even if they were taking both aspirin and clopidogrel. All other variables such as past medical history, smoking history and other medications were gathered using electronic medical records. Exclusion criteria were ongoing dialysis, history of renal transplantation, active liver disease or cirrhosis, quantitative $(\leq 150,000)$ or qualitative platelet dysfunction (known bleeding disorder, thrombophilia), exposure to erythropoiesis stimulating agents, blood products transfusion including platelets, documented loading dose of P2Y12 antagonist at the time of platelet reactivity testing, and active bleeding during hospital stay. The institutional review board at Einstein Medical Center approved the study. No extramural funding was used to support this work.

\section{Platelet Function Assays and Definition}


Platelet function was assessed using the VerifyNow Aspirin and VerifyNow P2Y12 analyzers (Ultegra Rapid Platelet-Function Assay; Accumetrics, San Diego, CA). These are point of care systems that measure rate and extent of light changes in whole blood as platelets aggregate over time in response to agonists that are specific to various antiplatelet medications (arachidonic acid and ADP, respectively for aspirin and clopidogrel). Results are reported as P2Y12 reactivity units (PRU) for clopidogrel and aspirin reactivity units (ARU) for aspirin. HTPR was defined based on recent published data as PRU>208 for clopidogrel and ARU >550 for aspirin ${ }^{15}$. Blood sampling and platelet reactivity assays were performed following original protocols; whole blood was collected from venous sites using 21 gauge or larger needle in a partial fill; $3.2 \%$ citrate vacuum collection tube (blue top), samples were obtained from extremities free of peripheral venous infusions and set a minimum of 30 minutes after collection before test was done but no longer than 4 hours.

\section{Renal Function and Proteinuria}

Renal function was classified based on estimated glomerular filtration rate (eGFR) using the serum creatinine at the time of platelet reactivity measurement. Albuminuria was detected based on a spot urine dipstick analysis at the time of admission. The dipstick urine test is a simple method of assessing overt albuminuria ${ }^{16}$. While the semi quantitative ability to assess the degree of albuminuria with a spot dipstick is limited by the specific gravity at the time of the test, given the retrospective nature of this study we used a cutoff of urine dipstick protein of $>30 \mathrm{mg} / \mathrm{dl}$ ( $>300$ to $500 \mathrm{mg} / \mathrm{g}$ on a spot-protein/creatinine ratio), to identify subjects with overt proteinuria, as microalbumin/creatinine ratios were not uniformly available in this cohort of patients. 
For final analysis, patients were classified into two groups; eGFr $>60 \mathrm{cc} / \mathrm{min}$ and $\mathrm{eGFR}<60 \mathrm{cc} / \mathrm{min}$.

\section{Clinical Definition and Outcome Measurement}

Patients admitted with ACE comprised acute coronary syndromes (unstable angina and myocardial infarction), cerebrovascular accidents (cerebrovascular accident and transient ischemic attack), and cardiovascular death. All cause mortality events reported in the Social Security Death Master File were recorded until December $31^{\text {st }}$ 2013.Thirty-day readmission rate due to ACE, length of stay (LOS), percutaneous coronary intervention, and incidence of stent thrombosis or re-stenosis were reviewed with a mean follow up of 520 days.

\section{Statistical analysis}

Student t-tests (two-tailed) and Mann-Whitney tests (two-tailed) were used to compare various clinical parameters, and Bonferroni correction was applied to adjust for multiple comparisons. Fisher's exact test was used to compare the percentage of patients with PRU >208 among the patient subgroups with and without DP Likelihood ratio $\mathrm{p}$ value was computed to compare the percentage of patients with PRU >208 among the patients with different eGFrs. Multivariate analysis was done using a logistic regression model to adjust the effects eGFr and DP on PRU binary outcome ( $>208$ or $\leq 208)$ and calculate the adjusted odds ratios. All the analyses were done using JMP 10.0 (SAS, Cary, NC) and PRISM 6.0 (GraphPad Software Inc., La Jolla, CA) softwares. 


\section{Results}

\section{Cohorts Characteristics}

A total of 261 of 285 patients studied qualified for final analysis, with 24 patients excluded from analysis for the following reasons: 2 patients had underlying cirrhosis while on antiplatelet medication, 9 patients were tested for platelet function despite no documentation of being on antiplatelet therapy based on outpatient and pharmacy records, 1 patient required transfusion of blood products, 7 patients were loaded with clopidogrel at the time of admission, and 5 blood samples were stored inappropriately resulting in in-vitro interaction and mistaken results according to the laboratory report.

Baseline demographic data and clinical characteristics of patients (based on their antiplatelet assay and HTPR status) are listed in Table 1. In our cohort 106 (40.6\%) patients taking daily clopidogrel were assayed for platelet function expressed as PRU, whereas $155(59.4 \%)$ patients taking daily aspirin were assayed for platelet function expressed as ARU. HTPR was found in $60.4 \%$ of patients taking clopidogrel (PRU $>208, n=64$ ), but only $16.1 \%$ of patients taking aspirin (ARU $>550, n=25$ ). Eighty seven percent $(n=92)$ of the subjects on clopidogrel were also on aspirin, and $32 \%$ $(n=49)$ of patients on aspirin were taking clopidogrel as well. There were no significant differences in clinical characteristics between subgroups, except subjects with an ARU $>550$ had a higher eGFR than patients with an ARU $\leq 550(\mathrm{p}=0.01)$. Forty two percent of patients with PRU $>208$ had evidence of DP $(n=27)$ whereas $13 \%$ of patients with PRU $\leq 208(\mathrm{n}=5)$ had DP at the time of the assay $(\mathrm{p}=0.01)$. When considering PRU as a continuous variable, there was a mild but significant association between PRU and HbA1c $\left(\mathrm{p}=0.02, \mathrm{r}^{2}=0.07\right)$. 


\section{Association of Dipstick Proteinuria and Renal Function on HTPR}

In patients on clopidogrel, DP was associated with PRU >208 (OR=4.93, Fisher's exact $\mathrm{p}=0.015$, Table 2 and Figure 1). Renal function was not associated with PRU values either when assessed using eGFR as a continuous score (using either MDRD or CKD-EPI creatinine formula when appropriate, data not shown). However, the prevalence of HTPR was $100 \%$ in $\mathrm{eGFr}<30 \mathrm{cc} / \mathrm{min}(\mathrm{n}=8,7$ had DP).

In multivariate analysis shown in Table 2, the association between DP and PRU were adjusted for multiple variables (eGFR, diabetes mellitus, history of smoking or use of protein pump inhibitors), using a logistic regression model, also eGFR calculation takes into account age, gender and race. For this purpose we grouped our sample into eGFr $>60 \mathrm{cc} / \mathrm{min}$ and $\mathrm{eGFR}<60 \mathrm{cc} / \mathrm{min}$. Here, DP, but not eGFR, remained significantly associated with PRU $>208$ in the multivariate model (adjusted OR=5.2, $\mathrm{p}=0.017$, Table 2).

In contrast, DP and eGFR did not demonstrate a significant association with HTPR in patients on aspirin. The eGFR were significantly higher in ARU >550 ( $\mathrm{p}=0.01$, Table 1).

\section{HTPR and Clinical Outcomes}

In our cohort, HTPR in patients on clopidogrel was not associated with the following outcomes: all cause mortality, LOS in hospital, 30 days readmission due to ACE, number of coronary interventions, in-stent thrombosis, in-stent stenosis (Table 1). In contrast, HTPR in patients on aspirin was significantly associated with higher all cause mortality $(5 \%$ versus $16 \%, \mathrm{p}=0.038)$.

However, in sub-analysis focusing on patients receiving clopidogrel who were admitted with either non ST segment myocardial infarction or ST segment myocardial 
infarction $(51.9 \%, \mathrm{n}=45$ and $\mathrm{n}=10$ respectively), there was a significant correlation between HTPR in patients and subsequent number of coronary catheterizations during the follow up period $\left(\mathrm{p}=0.009, \mathrm{r}^{2}=0.13,95 \%\right.$ CI for slope $=0.002$ to 0.011 , Figure 2 ). In addition, HTPR was significantly associated with 30 days readmission for MACE in this subgroup $\left(\mathrm{p}=0.03, \mathrm{r}^{2}=0.08\right)$. 


\section{Discussion}

The major finding of this study is that the presence of DP ( $\geq 300 \mathrm{mg} / \mathrm{g})$, independent of eGFR, is strongly associated with HTPR in patients on clopidogrel, but not in those on aspirin. In particular, after adjusting for potential cofounders, patients with DP had a 5-fold increase in the odds of having HTPR while on clopidogrel when compared with those without DP. While platelet reactivity is a metric of thrombosis and cardiac catheterization is a clinical driven decision, our data does suggest a modest association between HTPR and subsequent cardiac catheterizations, in the sub group of patients admitted with ACS

Up to one third of patients treated with clopidogrel do not display an adequate antiplatelet response ${ }^{17}$. In contrast, the prevalence of non-responders to aspirin is as low as 0 to $20 \%$, and its clinical significance is debatable $e^{4,18,19}$. Routine platelet function testing is not currently recommended and is considered a class IIB indication in high risk patient undergoing PCI and those prone to recurrent events according the American College of Cardiology Foundation/American Heart Association Task Force and the Society for Cardiovascular Angiography and Interventions ${ }^{20,21}$. Recently, the largest prospective multicenter registry on platelet reactivity and clinical outcomes after coronary artery implantation of drug-eluting stents (ADAPT-DES) showed that PRU after PCI was strongly related to subsequent stent thrombosis, and that adopting a cutoff value of $>208$ would reclassify the risk of definite stent thrombosis for $35 \%$ of the patients [unadjusted HR $2.54(95 \% \text { CI 1.55-4.16) } \mathrm{p}=0.0002]^{15}$. Thus, a recent consensus has adopted this new cutoff value as the marker of HTPR ${ }^{22}$,

Even subtle decrement in GFR is an independent risk factor for accelerated atherosclerosis and thrombotic events ${ }^{23,24}$. Although there are contrasting data, previous studies have linked CKD to HTPR putting patients in a higher risk 
category $^{9,11,25}$. A potential explanation for an abnormal response to ADP antagonist therapy in patients with $\mathrm{CKD}$ is an increased expression of multiple signaling pathways, higher levels of C-reactive protein, von Willenbrand factor and soluble Pselectin resulting in platelet hyper reactivity ${ }^{26,27}$. Conversely, there is also some evidence that GFR decline may not be associated with $\mathrm{HTPR}^{28}$.

Albuminuria precedes renal function decline and has been used as a surrogate of systemic inflammation and endothelial dysfunction, it is considered a strong independent risk for cardiovascular events regardless of its association with other well known risk factors for ACE such as hypertension and diabetes ${ }^{12,13,29}$. Recently it was associated with an increase risk of Periprocedural Myocardial Injury in Patients Undergoing Elective Coronary Stent Implantation ${ }^{30}$. Furthermore, reduction of albuminuria is associated with a decreased occurrence of $\mathrm{ACE}^{31}$. Araki et al demonstrated an independent association between albuminuria and early changes in activated platelet profiles of type 2 diabetic patients ${ }^{32}$. These patients were not on any ADP inhibitors and the association between albuminuria and HTPR was not assessed. Moreover, no analysis was perform based on eGFR and albuminuria.

The results presented in this study to our knowledge, are the first data to delineate an association between dipstick proteinuria and platelet reactivity, regardless of GFR quantification on single or dual antiplatelet therapy. We acknowledge that assessment of proteinuria with a dipstick is a "snapshot" view and that given the low number of events we cannot conclude any associations between HTPR and individual events. Larger studies are needed to establish this relationship. However our data does suggest that even a one time assessment of proteinuria in the setting of ACE, might have prognostic and therapeutic implications, including stepping up antiproteinuric therapy to optimize platelet inhibition in high risk patients. 
Interestingly $\mathrm{Tu}$ et al suggested that the combination of clopidogrel and angiotensin receptor blocker (Ibersantan) attenuated the progression of CKD including proteinuria through platelet inhibition and anti-inflammatory effects resulting in decreased glomerular fibrosis ${ }^{33}$. In addition, even in the non proteinuric patient at baseline, transient "stress related proteinuria" is well documented in the setting of critical illness, possible mechanisms including; capillary leak, endothelial injury and early tubular injury ${ }^{34}$. Thus, even if not detected in longitudinal studies, the association of HTPR with proteinuria at the time of ACE in itself might have prognostic implications.

\section{Study Limitations}

There are several limitations to consider in the interpretation of our findings. The current data derived from the observational study design do not permit causal inference among the reported associations, but rather are useful for hypothesis generation. Our criteria for selection of subjects included those with available data on platelet reactivity, which may represent a high-risk subset of patients to begin with. Although we attempted to assure compliance with antiplatelet medication by acquiring information from outpatient and pharmacy records, non-compliance could potentially explain the associations between DP, renal function and platelet reactivity. The association between DP and HTPR is limited by our small sample size, and larger studies are needed to confirm whether or not this association is in fact reproducible. We cannot exclude the possibility that other unmeasured confounders, including genetic polymorphisms, and other non-documented medications such as over the counter non-steroidal anti-inflammatory drugs or undiagnosed conditions like underlying malignancy might contribute to our findings. In addition, while dipstick assessment of albuminuria semi quantitatively is a useful and widely available 
screening tool, the accuracy is limited by the lack of precise quantification such as a spot albumin to creatinine ratio, or a 24-hour urine collection for albumin excretion and variations inspecific gravity at the time of testing. We cannot exclude with certainty the possibility of in vitro interaction in patients on simultaneous dual anti platelet therapy, even though the pharmacodynamics and pathways of platelet inhibition are different. Our analysis of clinical outcomes was limited to all-cause mortality, readmission to a single institution and number of interventions done by a single center cardiology practice.

\section{Conclusions}

To our knowledge this is the first study reporting an association between dipstick proteinuria and platelet reactivity. Here DP is independently associated with HTPR in patients taking clopidogrel; however this association was not seen in patients on aspirin. HTPR in patients on clopidogrel was associated with an increased rate of cardiac catheterizations and cardiovascular readmissions. Although the prevalence of aspirin resistance was low, it was significantly associated with all cause mortality.

\section{Disclosure}

None 


\section{References}

1. Antithrombotic Trialists C, Baigent C, Blackwell L, Collins R, Emberson J, Godwin J, Peto R, Buring J, Hennekens C, Kearney P, Meade T, Patrono C, Roncaglioni MC, Zanchetti A. Aspirin in the primary and secondary prevention of vascular disease: collaborative meta-analysis of individual participant data from randomised trials. Lancet 2009;373:1849-1860.

2. Patrono C, Andreotti F, Arnesen H, Badimon L, Baigent C, Collet JP, De Caterina R, Gulba D, Huber K, Husted S, Kristensen SD, Morais J, Neumann FJ, Rasmussen LH, Siegbahn A, Steg PG, Storey RF, Van de Werf F, Verheugt F. Antiplatelet agents for the treatment and prevention of atherothrombosis. European heart journal 2011;32:2922-2932.

3. Patrono C, Coller B, FitzGerald GA, Hirsh J, Roth G. Platelet-active drugs: the relationships among dose, effectiveness, and side effects: the Seventh ACCP Conference on Antithrombotic and Thrombolytic Therapy. Chest 2004;126:234S$264 S$.

4. Krasopoulos G, Brister SJ, Beattie WS, Buchanan MR. Aspirin "resistance" and risk of cardiovascular morbidity: systematic review and meta-analysis. Bmj 2008;336:195-198.

5. Campo G, Fileti L, de Cesare N, Meliga E, Furgieri A, Russo F, Colangelo S, Brugaletta S, Ferrari R, Valgimigli M, Investigators TR. Long-term clinical outcome based on aspirin and clopidogrel responsiveness status after elective percutaneous coronary intervention: a $3 \mathrm{~T} / 2 \mathrm{R}$ (tailoring treatment with tirofiban in patients showing resistance to aspirin and/or resistance to clopidogrel) trial substudy. Journal of the American College of Cardiology 2010;56:1447-1455. 
6. Brar SS, ten Berg J, Marcucci R, Price MJ, Valgimigli M, Kim HS, Patti G, Breet NJ, DiSciascio G, Cuisset T, Dangas G. Impact of platelet reactivity on clinical outcomes after percutaneous coronary intervention. A collaborative meta-analysis of individual participant data. Journal of the American College of Cardiology 2011;58:1945-1954.

7. Price MJ, Angiolillo DJ, Teirstein PS, Lillie E, Manoukian SV, Berger PB, Tanguay JF, Cannon CP, Topol EJ. Platelet reactivity and cardiovascular outcomes after percutaneous coronary intervention: a time-dependent analysis of the Gauging Responsiveness with a VerifyNow P2Y12 assay: Impact on Thrombosis and Safety (GRAVITAS) trial. Circulation 2011;124:1132-1137.

8. Coca SG, Krumholz HM, Garg AX, Parikh CR. Underrepresentation of renal disease in randomized controlled trials of cardiovascular disease. JAMA : the journal of the American Medical Association 2006;296:1377-1384.

9. Angiolillo DJ, Bernardo E, Capodanno D, Vivas D, Sabate M, Ferreiro JL, Ueno M, Jimenez-Quevedo P, Alfonso F, Bass TA, Macaya C, Fernandez-Ortiz A. Impact of chronic kidney disease on platelet function profiles in diabetes mellitus patients with coronary artery disease taking dual antiplatelet therapy. Journal of the American College of Cardiology 2010;55:1139-1146.

10. Tanrikulu AM, Ozben B, Koc M, Papila-Topal N, Ozben T, Caymaz O. Aspirin resistance in patients with chronic renal failure. Journal of nephrology 2011;24:636646.

11. Gremmel T, Muller M, Steiner S, Seidinger D, Koppensteiner R, Kopp CW, Panzer S. Chronic kidney disease is associated with increased platelet activation and poor response to antiplatelet therapy. Nephrology, dialysis, transplantation : official 
publication of the European Dialysis and Transplant Association - European Renal Association 2013;28:2116-2122.

12. Moser M, Sowers JR, Black HR. Microalbuminuria, chronic renal disease, and the effects of the metabolic syndrome on cardiovascular events. Journal of clinical hypertension 2007;9:551-556.

13. Thoenes $M$, Bramlage $P$, Khan BV, Schieffer $B$, Kirch $W$, Weir MR. Albuminuria: pathophysiology, epidemiology and clinical relevance of an emerging marker for cardiovascular disease. Future cardiology 2007;3:519-524.

14. Weir MR. Microalbuminuria and cardiovascular disease. Clinical journal of the American Society of Nephrology : CJASN 2007;2:581-590.

15. Stone GW, Witzenbichler B, Weisz G, Rinaldi MJ, Neumann FJ, Metzger DC, Henry TD, Cox DA, Duffy PL, Mazzaferri E, Gurbel PA, Xu K, Parise H, Kirtane AJ, Brodie BR, Mehran R, Stuckey TD, Investigators A-D. Platelet reactivity and clinical outcomes after coronary artery implantation of drug-eluting stents (ADAPT-DES): a prospective multicentre registry study. Lancet 2013;382:614-623.

16. Constantiner M, Sehgal AR, Humbert L, Constantiner D, Arce L, Sedor JR, Schelling JR. A dipstick protein and specific gravity algorithm accurately predicts pathological proteinuria. American journal of kidney diseases : the official journal of the National Kidney Foundation 2005;45:833-841.

17. Nguyen TA, Diodati JG, Pharand C. Resistance to clopidogrel: a review of the evidence. Journal of the American College of Cardiology 2005;45:1157-1164.

18. Nielsen HL, Kristensen SD, Thygesen SS, Mortensen J, Pedersen SB, Grove EL, Hvas AM. Aspirin response evaluated by the VerifyNow Aspirin System and light transmission aggregometry. Thrombosis research 2008;123:267-273. 
19. Wang JC, Aucoin-Barry D, Manuelian D, Monbouquette R, Reisman M, Gray W, Block PC, Block EH, Ladenheim M, Simon DI. Incidence of aspirin nonresponsiveness using the Ultegra Rapid Platelet Function Assay-ASA. The American journal of cardiology 2003;92:1492-1494.

20. Levine GN, Bates ER, Blankenship JC, Bailey SR, Bittl JA, Cercek B, Chambers CE, Ellis SG, Guyton RA, Hollenberg SM, Khot UN, Lange RA, Mauri L, Mehran R, Moussa ID, Mukherjee D, Nallamothu BK, Ting HH. 2011 ACCF/AHA/SCAI Guideline for Percutaneous Coronary Intervention: executive summary: a report of the American College of Cardiology Foundation/American Heart Association Task Force on Practice Guidelines and the Society for Cardiovascular Angiography and Interventions. Circulation 2011;124:2574-2609.

21. Jneid H, Anderson JL, Wright RS, Adams CD, Bridges CR, Casey DE, Jr., Ettinger SM, Fesmire FM, Ganiats TG, Lincoff AM, Peterson ED, Philippides GJ, Theroux P, Wenger NK, Zidar JP. 2012 ACCF/AHA focused update of the guideline for the management of patients with unstable angina/non-ST-elevation myocardial infarction (updating the 2007 guideline and replacing the 2011 focused update): a report of the American College of Cardiology Foundation/American Heart Association Task Force on Practice Guidelines. Journal of the American College of Cardiology 2012;60:645-681.

22. Tantry US, Bonello L, Aradi D, Price MJ, Jeong YH, Angiolillo DJ, Stone GW, Curzen N, Geisler T, Ten Berg J, Kirtane A, Siller-Matula J, Mahla E, Becker RC, Bhatt DL, Waksman R, Rao SV, Alexopoulos D, Marcucci R, Reny JL, Trenk D, Sibbing D, Gurbel PA. Consensus and Update on the Definition of On-Treatment Platelet Reactivity to ADP Associated with Ischemia and Bleeding. Journal of the American College of Cardiology 2013. 
23. Muntner $\mathrm{P}, \mathrm{He} \mathrm{J}$, Hamm L, Loria $\mathrm{C}$, Whelton $\mathrm{PK}$. Renal insufficiency and subsequent death resulting from cardiovascular disease in the United States. Journal of the American Society of Nephrology : JASN 2002;13:745-753.

24. Mann JF, Gerstein HC, Pogue J, Bosch J, Yusuf S. Renal insufficiency as a predictor of cardiovascular outcomes and the impact of ramipril: the HOPE randomized trial. Annals of internal medicine 2001;134:629-636.

25. Muller C, Caillard S, Jesel L, El Ghannudi S, Ohlmann P, Sauleau E, Hannedouche T, Gachet C, Moulin B, Morel O. Association of estimated GFR with platelet inhibition in patients treated with clopidogrel. American journal of kidney diseases : the official journal of the National Kidney Foundation 2012;59:777-785.

26. Landray MJ, Wheeler DC, Lip GY, Newman DJ, Blann AD, McGlynn FJ, Ball S, Townend JN, Baigent C. Inflammation, endothelial dysfunction, and platelet activation in patients with chronic kidney disease: the chronic renal impairment in Birmingham (CRIB) study. American journal of kidney diseases : the official journal of the National Kidney Foundation 2004;43:244-253.

27. Zawada AM, Rogacev KS, Muller S, Rotter B, Winter P, Fliser D, Heine GH. Massive Analysis of cDNA Ends (MACE) and miRNA expression profiling identifies proatherogenic pathways in chronic kidney disease MACE and miRNA profiling in CKD. Epigenetics : official journal of the DNA Methylation Society 2013;9.

28. Mangiacapra F, Cavallari I, Barbato E, Ricottini E, Patti G, Vizzi V, D'Ambrosio A, De Bruyne B, Wijns W, Di Sciascio G. Impact of chronic kidney disease on platelet reactivity and outcomes of patients receiving clopidogrel and undergoing percutaneous coronary intervention. Am J Cardiol 2014;113:1124-1129.

29. Foster MC, Hwang SJ, Larson MG, Parikh NI, Meigs JB, Vasan RS, Wang TJ, Levy D, Fox CS. Cross-classification of microalbuminuria and reduced glomerular 
filtration rate: associations between cardiovascular disease risk factors and clinical outcomes. Archives of internal medicine 2007;167:1386-1392.

30. Osugi N, Suzuki S, Ishii H, Yasuda Y, Shibata Y, Tatami Y, Ota T, Kawamura Y, Okumura S, Tanaka A, Inoue Y, Matsuo S, Murohara T. Impact of Albuminuria on the Incidence of Periprocedural Myocardial Injury in Patients Undergoing Elective Coronary Stent Implantation. The American journal of cardiology 2014.

31. Araki S, Haneda M, Koya D, Hidaka H, Sugimoto T, Isono M, Isshiki K, ChinKanasaki M, Uzu T, Kashiwagi A. Reduction in microalbuminuria as an integrated indicator for renal and cardiovascular risk reduction in patients with type 2 diabetes. Diabetes 2007;56:1727-1730.

32. Araki S, Matsuno H, Haneda M, Koya D, Kanno Y, Itho J, Kishi A, Isshiki K, Sugimoto T, Maegawa H, Kashiwagi A, Uzu T. Correlation between albuminuria and spontaneous platelet microaggregate formation in type 2 diabetic patients. Diabetes care 2009;32:2062-2067.

33. Tu X, Chen $X$, Xie Y, Shi S, Wang J, Chen Y, Li J. Anti-inflammatory renoprotective effect of clopidogrel and irbesartan in chronic renal injury. Journal of the American Society of Nephrology : JASN 2008;19:77-83.

34. Gai M, Cantaluppi V, Fenocchio C, Motta D, Masini S, Pacitti A, Lanfranco G. Presence of protein fragments in urine of critically ill patients with acute renal failure: a nephrologic enigma. Clin Chem 2004;50:1822-1824. 


\section{Table and Figure Legends}

Table 1: Demographics and Baseline Characteristics of Patients at the Time of Admission Grouped by Antiplatelet Therapy and Platelet Reactivity Assay

Figure 1: The Separate Relationships of Estimated Glomerular Filtration Rate and Dipstick Proteinuria with HTPR in ACE Patients Treated with Clopidogrel Footnote for Figure 1:

Column graph demonstrating prevalence of HTPR across patients grouped based on $\mathrm{eGFR} \geq 60 \mathrm{ml} / \mathrm{min} / 1.73 \mathrm{~m}^{2}$ and $\mathrm{eGFR}<60 \mathrm{ml} / \mathrm{min} / 1.73 \mathrm{~m}^{2}$ and the presence of DP. HTPR is defined as PRU>208 for clopidogrel. Renal function was defined by estimated GFR calculated using Modification of Diet in Renal Disease (MDRD) equation that calculates creatinine clearance based on patient's gender, age and ethnicity. Spot Dipstick Proteinuria (DP) was defined as dipstick protein of $>30 \mathrm{mg} / \mathrm{dl}$ (>300 to $500 \mathrm{mg} / \mathrm{g}$ on a spot-protein/creatinine ratio. Fisher's exact test was used to analyze the differences of HTPR prevalence across DP status.

Table 2: Multivariable Logistic Regression Model Study of Factors Associated with High on Treatment Platelet Reactivity.

Figure 2: Linear regression between platelet reactivity unit (PRU) and number of cardiac catheterization in patients presenting with acute coronary syndrome (ACS) 
Figure 1

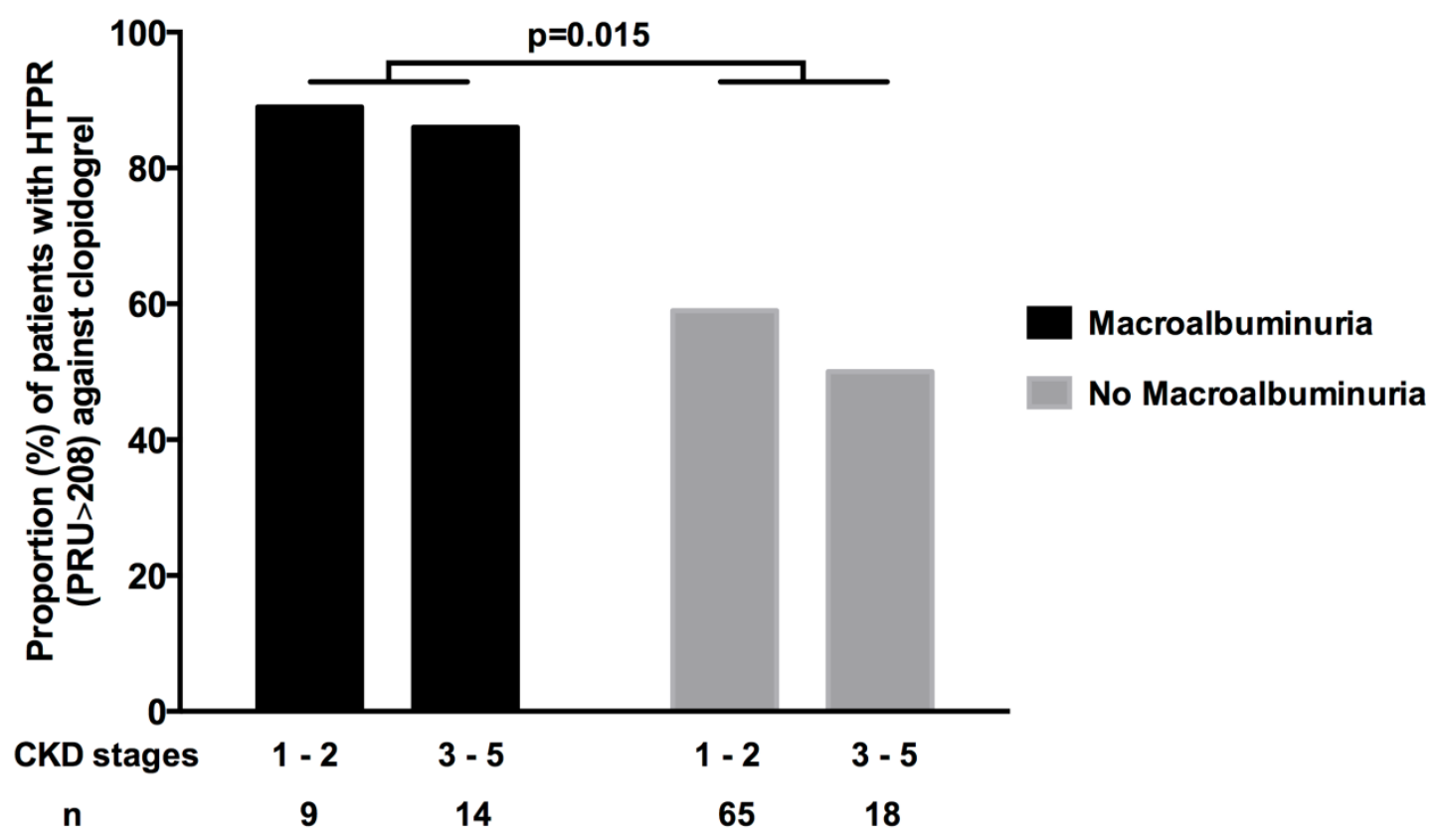


Figure 2

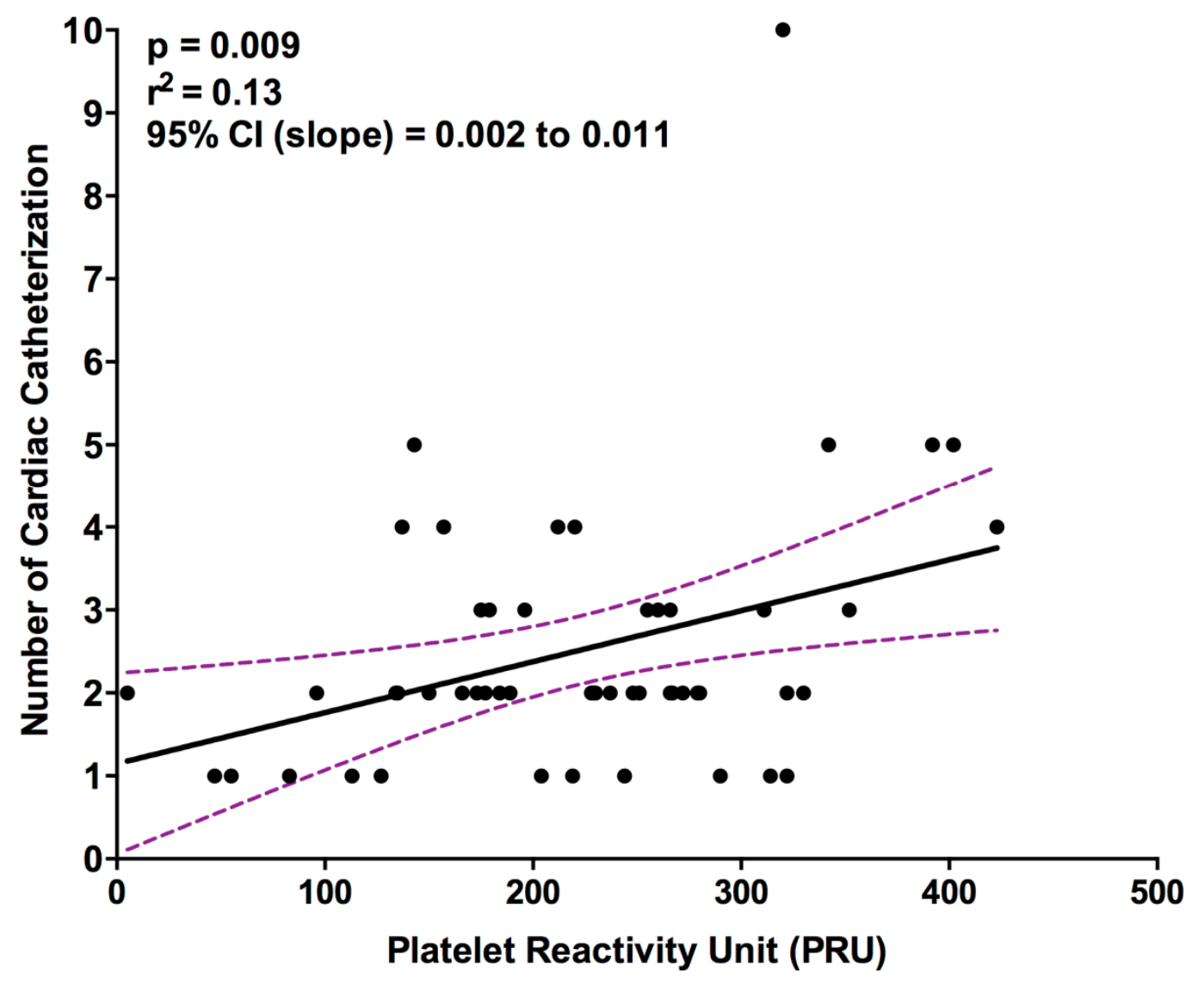


Table 1

Table 1: Demographics and Baseline Characteristics of Patients at the Time of Admission Grouped by the Antiplatelet Treatment and Platelet Reactivity Assay

\begin{tabular}{|c|c|c|c|c|c|c|}
\hline & \multicolumn{3}{|c|}{ Patients on clopidogrel } & \multicolumn{3}{|c|}{ Patients on aspirin } \\
\hline & $\begin{array}{c}\text { All } \\
\text { subjects } \\
(n=106)\end{array}$ & $\begin{array}{c}\text { PRU } \leq \\
208 \\
(n=42)\end{array}$ & $\begin{array}{c}\text { PRU > } \\
208 \\
(n=64)\end{array}$ & $\begin{array}{c}\text { All } \\
\text { subjects } \\
(n=155)\end{array}$ & $\begin{array}{c}A R U \leq \\
550 \\
(n=130)\end{array}$ & $\begin{array}{c}\text { ARU > } \\
550 \\
(n=25)\end{array}$ \\
\hline \multicolumn{7}{|l|}{ Demographics } \\
\hline Mean age $(y \pm S D)$ & $\begin{array}{c}63.4 \pm \\
12.3\end{array}$ & $\begin{array}{l}65.1 \pm \\
12.7\end{array}$ & $\begin{array}{c}62.3 \pm \\
12.0\end{array}$ & $\begin{array}{c}67.3 \pm \\
13.3\end{array}$ & $\begin{array}{c}67.4 \pm \\
12.9\end{array}$ & $\begin{array}{c}66.4 \pm \\
15.9\end{array}$ \\
\hline Gender (\% male) & 49.1 & 50 & 48.4 & 38.1 & 36.9 & 44 \\
\hline \multicolumn{7}{|l|}{$\begin{array}{l}\text { Past medical } \\
\text { history }\end{array}$} \\
\hline Hypertension (\%) & 92.4 & 88.1 & 95.3 & 90.9 & 90.8 & 92 \\
\hline Diabetes (\%) & 60 & 54.7 & 63.4 & 52.3 & 52.3 & 52 \\
\hline CAD (\%) & 80.9 & 88.1 & 76.1 & 34.2 & 33 & 44 \\
\hline PVD (\%) & 22.1 & 33.3 & 14.5 & 10.4 & 11.5 & 4.2 \\
\hline $\mathrm{PCl}(\%)$ & 71.4 & 76.1 & 68.2 & 18.2 & 20.8 & 4.2 \\
\hline CABG (\%) & 17.1 & 19 & 15.8 & 6.5 & 6.9 & 4.2 \\
\hline TIA or CVA (\%) & 48.1 & 42.8 & 51.6 & 85.8 & 79.2 & 80 \\
\hline CHF (\%) & 31.3 & 40 & 25.4 & 18.8 & 19.8 & 13 \\
\hline Smoking (\%) & 41.5 & 40.4 & 42.1 & 36.2 & 35.2 & 41.7 \\
\hline $\begin{array}{l}\text { Medical therapy } \\
\text { Median } \\
\text { medications (n) }\end{array}$ & 9 & 10 & 9 & 8 & 8 & 8 \\
\hline Aspirin (\%) & 86.7 & 83.3 & 89.1 & 100 & 100 & 100 \\
\hline Clopidogrel (\%) & 100 & 100 & 100 & 32.3 & 31.5 & 36 \\
\hline PPI (\%) & 35.8 & 28.5 & 40.6 & 30.5 & 28.7 & 40 \\
\hline ACE-I or ARB (\%) & 68.8 & 73.8 & 65.6 & 59.4 & 56.9 & 72 \\
\hline Beta-blocker (\%) & 75.4 & 76.1 & 75 & 45.8 & 42.3 & 64 \\
\hline Statin (\%) & 92.5 & 90.4 & 93.7 & 82.6 & 83.1 & 80 \\
\hline Loop diuretics (\%) & 44.3 & 45.2 & 43.7 & 37.4 & 38.5 & 32 \\
\hline \multicolumn{7}{|l|}{ Clinical data } \\
\hline Creatinine $(\mathrm{mg} / \mathrm{dL})$ & $1.2 \pm 0.7$ & $1.1 \pm 0.3$ & $1.3 \pm 0.9$ & $1.2 \pm 0.6$ & $1.2 \pm 0.6$ & $1.0 \pm 0.4$ \\
\hline $\mathrm{eGFR}_{\mathrm{MDRD}}(\mathrm{mL} / \mathrm{min})$ & $\begin{array}{l}77.8 \pm \\
36.9\end{array}$ & $\begin{array}{c}80.2 \pm \\
40.7\end{array}$ & $\begin{array}{c}76.2 \pm \\
34.4\end{array}$ & $\begin{array}{l}78.8 \pm \\
38.0\end{array}$ & $\begin{array}{c}75.4 \pm \\
32.9\end{array}$ & $\begin{array}{l}96.4 \pm \\
54.5 *\end{array}$ \\
\hline $\begin{array}{l}\text { eGFR } \\
\text { (mL/min) }\end{array}$ & $\begin{array}{l}71.7 \pm \\
28.7\end{array}$ & $\begin{array}{l}72.6 \pm \\
26.0\end{array}$ & $\begin{array}{l}71.0 \pm \\
30.6\end{array}$ & $\begin{array}{l}71.0 \pm \\
27.9\end{array}$ & $\begin{array}{l}69.0 \pm \\
27.5\end{array}$ & $\begin{array}{l}81.5 \pm \\
28.5^{*}\end{array}$ \\
\hline $\begin{array}{l}\text { Dipstick } \\
\text { Proteinuria (\%) }\end{array}$ & 34.7 & 13 & 42.6 & 33.8 & 34.5 & 26.3 \\
\hline Median LV-EF (\%) & 55 & 50 & 55 & 55 & 55 & 55 \\
\hline HbA1C (\%) & $7.6 \pm 2$ & $7.2 \pm 2$ & $7.8 \pm 2$ & $7.2 \pm 1.9$ & $7.3 \pm 1.7$ & $7 \pm 2.5$ \\
\hline \multicolumn{7}{|l|}{ Outcomes } \\
\hline $\begin{array}{l}\text { All cause mortality } \\
\text { (\%) }\end{array}$ & 8.4 & 7.1 & 9.3 & 5.8 & 5 & \\
\hline $\begin{array}{l}\text { LOS in hospital } \\
\text { (days) }\end{array}$ & 5.5 & 4.5 & 6.2 & 4.1 & 4.2 & 3.6 \\
\hline
\end{tabular}




\begin{tabular}{lccc|ccc}
$\begin{array}{l}30 \text { days } \\
\text { readmissions }(\mathbf{n})\end{array}$ & 2.1 & 1.7 & 2.3 & 1.3 & 1.3 & 1.5 \\
$\quad$ DVT or PE (\%) & 1.8 & 0 & 3.1 & 7.7 & 6.2 & 16 \\
$\begin{array}{l}\text { Coronary } \\
\text { catheterizations (n) } \\
\text { In-stent stenosis }\end{array}$ & 2.4 & 2.3 & 2.5 & 1.7 & 1.7 & 1.3 \\
$\begin{array}{l}\text { (\%) } \\
\text { In-stent thrombosis }\end{array}$ & 38.1 & 41.4 & 35.3 & 14.8 & 16.7 & 0 \\
$(\%)$ & 13.6 & 11.5 & 15.2 & 0 & 0 & 0 \\
\hline
\end{tabular}

Note: * denotes $p<0.05$ when compared the subgroups in bold

Abbreviations: $A C E-I$ = angiotensin-converting-enzyme inhibitor; $A R B=$ angiotensin II receptor blockers; $\quad A R U=$ aspirin reactivity unit; $\quad C A B G=$ coronary artery bypass graft; $C A D=$ coronary artery disease; CHF = congestive heart failure; CVA cerebrovascular accident; DVT = deep vein thrombosis; eGFR $\mathrm{R}_{\mathrm{CKD} \text {-EPI Creatinine }}=$ estimated glomerular filtration rate (Chronic Kidney Disease Epidemiology Collaboration formula); eGFR $_{\mathrm{MDRD}}=$ estimated glomerular filtration rate (Modification of Diet in Renal Disease formula); HbA1c = hemoglobin A1c; LOS = length of stay; $\mathrm{LV}-\mathrm{EF}=$ left ventricular ejection fraction; $\mathrm{PCl}=$ percutaneous coronary intervention; $\mathrm{PE}=$ pulmonary embolism; $\mathrm{PPI}=$ protein pump inhibitor; $\mathrm{PRU}=$ platelet reactivity unit; $P V D=$ peripheral vascular disease $; \mathrm{TIA}=$ transient ischemic attack 
Table 2

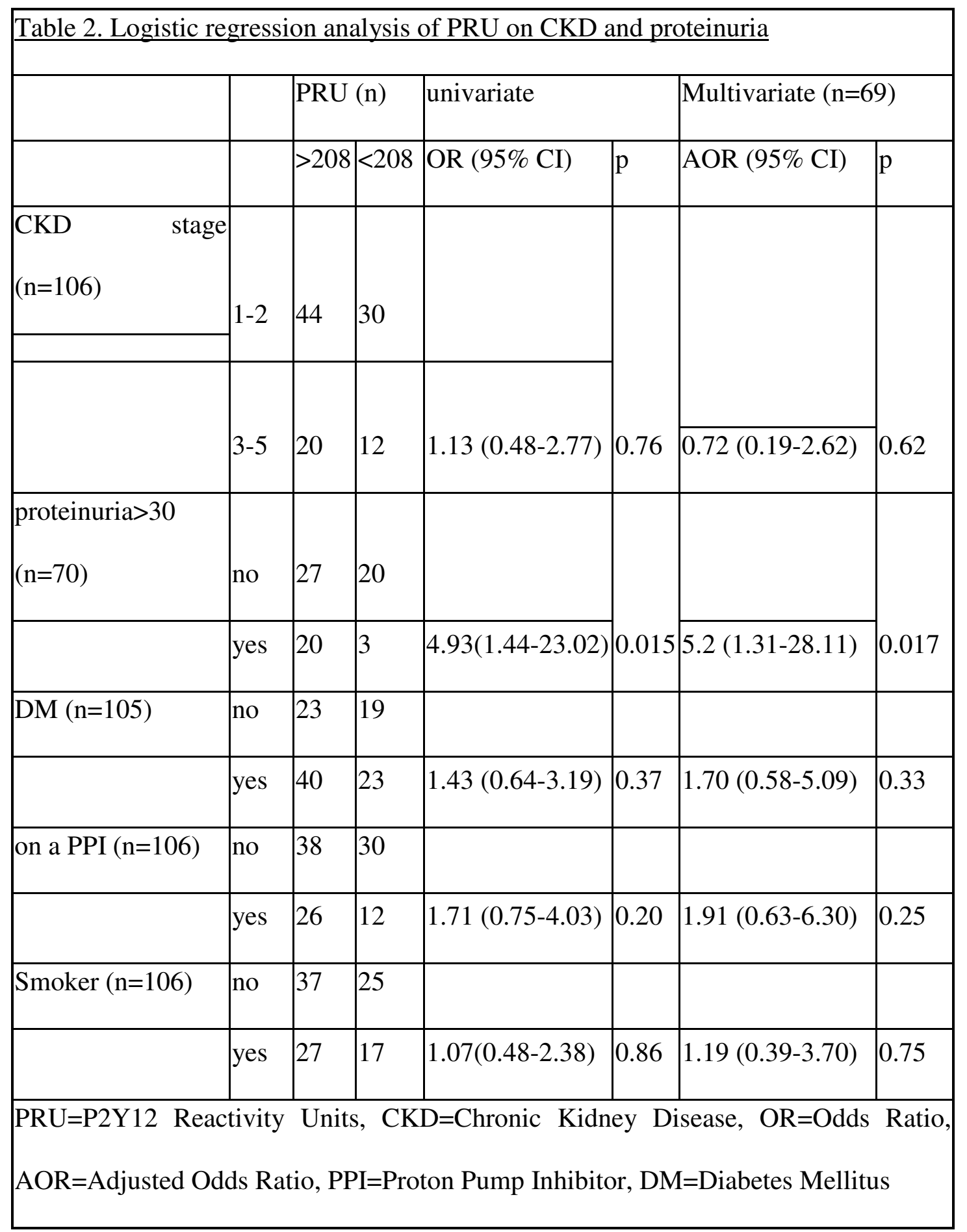

